Article

\title{
Economic and Environmental Performance of the Agricultural Sectors of the Selected EU Countries
}

\author{
Artiom Volkov ${ }^{1}\left[\right.$, Mangirdas Morkunas ${ }^{2}$, Tomas Balezentis ${ }^{1, *} \mathbb{C}$ and Vaida Šapolaitė ${ }^{1}$ \\ 1 Lithuanian Institute of Agrarian Economics, A. Vivulskio str. 4A-13, 03220 Vilnius, Lithuania; \\ artiom.volkov@laei.lt (A.V.); vaida.sapolaite@laei.lt (V.Š.) \\ 2 Faculty of Economics and Business, Mykolas Romeris University, Ateities str. 20, LT-08303 Vilnius, Lithuania; \\ morkunas.mangirdas@gmail.com \\ * Correspondence: tomas@laei.lt
}

Received: 21 November 2019; Accepted: 1 February 2020; Published: 7 February 2020

\begin{abstract}
This paper aims at to identify the differences in the performance of the agricultural sectors in the selected European Union Member States. The research covers 21 countries in the period from 2007-2017. The paper uses data from the Farm Accountancy Data Network (FADN). Three types of sectors were considered: Crop farming (wheat and rapeseed), specialist milk, and specialist cattle. The sector's performance was measured by calculating the aggregate scores using the VIKOR technique. The panel regression model was also used to estimate and assess the technical and economic determinants of the sector's performance. The obtained results indicated that the new EU Member States showed higher levels of performance compared to the old Member States. This finding may be attributed to the fact that some of the production factors in the new EU Member States are still under-valued compared to those of the old EU Member States.
\end{abstract}

Keywords: agriculture; European Union; performance indicators; VIKOR

\section{Introduction}

Since the expansion of the European Union (EU), significant funding under the Common Agricultural Policy (CAP) and structural funds umbrella has been allocated to ensure the renewal of agricultural machinery in the new EU Member States. This was done to improve the industrial performance (productivity) of these countries [1] and hasten the convergence between old and new Member States. Measures such as technical efficiency were applied to the agricultural sector to identify its performance gaps [2,3]. In addition to the industrial performance, the ecological considerations are also important in terms of sustainable development [4]. Sharma and Shardendu [5] revealed that improvement in agricultural performance was positively linked to the sustainability levels of the rural regions of a particular country. These findings were furthered by Smith et al. [6], pointing out the positive impact of agriculture on the sustainable development of rural communities.

This motivated us to compare the preconditions of rural sustainability across the EU Member States in order to understand which of them had the strongest basis in the sustainable development of their rural regions. Alongside the economic objectives, the concept of sustainability poses certain environmental objectives [7-11]. In order to answer the question about which countries within the EU possess the most formidable base for the formation of rural sustainability, we compared 21 EU Member States in terms of their agricultural performance. Additionally, we compared the agricultural sectors of the countries under analysis in terms of air pollutant emission intensity (per ha) in order to relate economic and environmental performance. The composite performance indicators were calculated for the three agricultural sectors types, namely crop farming, specialist milk, and specialist cattle. 


\section{Literature Review}

\subsection{Factors Influencing Agricultural Performance}

Agricultural performance can be measured by applying composite indicators. One of the concepts is the technical efficiency [12]. The scientific literature dealing with the technical efficiency can be separated into a few interdependent streams. One of the streams describes the phenomenon of technical efficiency; it is used as a constant regardless of the researched variables. Nymeck Binam et al. [13] found that technical efficiency was virtually uniform throughout the whole country and practically did not depend on the cultivated crop type. This significant finding allowed us to construct our research design, treating each country as a homogeneous entity. It also supplemented the idea of researching crop farming in general, not distinguishing between wheat, rye, etc. The stability of the technical efficiency within the researched country regardless of its regions was also documented by Bokusheva et al. [14]. Masterson [15] and de Freitas et al. [16] found that there was no direct link between technical efficiency and farm size. This was contradicted by Haq et al. [17], who found that small farmers were substantially more technically efficient. This interesting finding, which did not correspond to classical examples of the increasing efficiency due to economies of scale [18], emphasized the dissimilarity of agriculture compared to other economic sectors. Technical efficiency was also researched with respect to the age of farmers [19], also showing no statistically significant difference between age groups, although Gul et al. [20] provided a contrary argument. The robustness of the technical efficiency indicators was assessed by Blazejcyk-Majka and Kala [21], who used different measurement techniques, but obtained very similar results; however, it was very susceptible to extreme weather conditions [22]. Variations in climate conditions and their impacts on the technical efficiency were modeled by Diallo et al. [23]. Subsidies and their impact on the technical efficiency have also received attention in the literature. Latruffe et al. [24] focused on the Western European countries and found that subsidies may have a different impact on the technical efficiency of farming. This may be attributed to the fact that financial support that is too big curtails the incentives for more efficient production and management because this income stabilization tool is enough to ensure acceptable standards of living for the farmers, who will not put all possible effort into achieving this. The negative effect of subsidies on the technical efficiency was prevalent in the research of Minviel and Latruffe [25], showing that there were many more cases in which the subsidies negatively affected the output of farms, then it showed positive results. The ambiguity of these results should be also credited to different calculation models and different theoretical assumptions accepted, although these findings correspond to the presumptions of Lachaal [26] about the negative impact of government subsidies on farming efficiency. Zhu et al. [27], researching the impact of direct payments under CAP on the technical efficiency of those of the most advanced agricultural sectors, noticed that in the most advanced agricultural sectors (in terms of technical efficiency), the subsidies had a negative effect, lowering the technical efficiency level, but in slightly less advanced ones, it showed a positive outcome. This raises the idea that various forms of protectionism are preferred in less developed economic sectors; thus, more developed economies should place their emphasis on liberal free trade and market relations in order to facilitate growth and efficiency. Mehta [28] focused on the effect the technical efficiency had on the labor market, stressing its impact on lowering demand for labor in agriculture, but also showing its negative consequences during peak moments. Siddique et al. [29] showed a strong correlation between the education level of farmers and the technical efficiency level. The cost perspective dominated the research of Hasnain et al. [30], showing that increases in the prices of at least one of the production factors significantly affected the technical efficiency in developing economies. This finding, contradicting the mainstream theory about the robustness of the technical efficiency indicator, can be explained by the fragility and lack of resilience of various economic sectors in the developing world compared to developed economies.

An important research area is concentrated at identifying the determinants of technical efficiency in agriculture. Nowak et al. [31] suggested capital expenditures, e.g., investment in machinery, as a determinant of the technical efficiency. The importance of investments into machinery was also 
stressed by Huy and Nguyen [32]. Siddique et al. [29] noted a strong correlation between the education level of farmers and level of the technical efficiency. The emphasis on farmers' characteristics was also confirmed in the context of the small household farms [33].

Temoso et al. [34] related efficiency and productivity gains to output growth in agriculture. The changes in consumer income and preferences are considered as determinants of technical efficiency of vegetable farming [35], as the rapid changes in consumer preferences preclude farmers from specialization gains and distort investment decisions. Market imperfections are considered the main determinant of efficiency by Souza and Gomes [36]. Čehura [37] identified the quality of management processes as the main driving force of technical efficiency. Varasani et al. [38] found soil quality to be a determinant of the agricultural technical efficiency. Ahmad and Afzal [39] argue that technical efficiency is related to the economies of scale.

Another body of literature aims to reveal the macro level determinants of technical efficiency. Ho and Shimada [40] showed that climate change has negative impact on the agricultural technical efficiency in a short run. Anyway, climate change may trigger changes that positively affect the technical efficiency in medium and long run. Khatazza et al. [41] discussed the effects of shadow economy on the agricultural technical efficiency. Moreno-Moreno et al. [42] showed how environmental issues affect technical efficiency by directing the technological innovations progress towards predefined path. Environmental concerns were also identified as a determinant of efficiency by Buckley and Carney [43] who showed that improved economic performance (indicated by increased technical efficiency) of agricultural entities can serve as a basis for pollution mitigation.

\subsection{Linkages between Agricultural Performance and Rural Sustainability}

You and Zhang [44] considered the economic efficiency as one of the key pillars for rural sustainability. Nazzaro and Marotta [45] analyzed the link between the economic viability of agriculture and rural communities within the EU. Zeller et al. [46] concluded that more economically efficient agricultural practices create favorable conditions for rural development, including social and cultural aspects. Rockstrom et al. [47] stressed that increasing agricultural efficiency increases prosperity and sustainability not only for rural but also for the whole population. Akroyd [48] argued that increase in rural sustainability is related to implementation of modern management practices in agriculture. This point was supported by Babych [49] who also place emphasis on novel agricultural management practices. Some studies [50-52] consider agricultural efficiency gains as the main tool for alleviating poverty and ensuring sustainable rural development. This was supported by Edwards [53] who documented the changes in rural development rendered by the expansion of agricultural activities. Thuita and Ouma [54] showed how improvements in agricultural performance not only helped to increase the living standards, but also to substantially decreased inequality in the rural regions of the developing countries. Evans and Yarwood [55] put emphasis on the primary sector and its viability in the context of sustainability of rural regions.

Mansfield [56] demonstrated that sustainable agriculture contributes to communities in rural regions, thus serving as a basis for social sustainability. Importance of farming in maintaining social sustainability was also noted by Janker et al. [57]. De los Rios et al. [58] identified agriculture as a contributor to social sustainability in rural regions trough cooperative social learning and voluntary knowledge sharing. Gathorne-Hardy [59] documented that agricultural intensification may lead to increased economic efficiency which improves economic dimension of rural sustainability but this is at the expense of decrease in social and, especially, environmental dimensions. The latter conflict is also noted by Carles et al. [60], Bowers and Cheshire [61], Clark and Tilman [62], Zhang et al. [63], Devkota et al. [64], and Etingoff [65]. Czyżewski et al. [66,67] considered agriculture as a major actor determining environmental sustainability of rural regions. These findings motivate us to include environmental indicators when evaluating the performance of agricultural. 


\section{Methods}

For construction of the composite indicator of the performance of the agriculture, we used four variables: Land, permanent crops and quotas (LPCQ); buildings (B); machinery (M); breeding livestock (BL). These variables are divided by the gross farm income (GFI). These indicators are widely used in assessing agricultural performance [68-73]. Data from the Farm Accountancy Data Network (FADN) for the period from 2007-2017 are used for the analysis [74]. The research covers the three main types of farming (specialist cereals, oilseeds, and protein crops, specialist milk, and specialist cattle). Note that the use of the Net Farm Income would render more nuanced patterns of the farm performance, yet this indicator is often negative in the new EU Member States. This precludes us from using it in the further analysis. Due to data availability, the performance of such countries as Belgium, the Netherlands, Greece, Malta, Cyprus, Luxembourg, and Ireland has not been assessed.

Multi-criteria analysis involves weighting of the criteria. In this study, the entropy method was used to determine the importance of the four above-mentioned indicators. The vector normalization is applied to normalize the initial data for the entropy method [74]:

$$
\hat{r}_{i, j}=\frac{r_{i, j}}{\sum_{j=1}^{n} r_{i, j}},
$$

where $r_{i, j}$ are the values of indicators with $i=1,2, \ldots, m$ and $j=1,2, \ldots, n ; m$ represents the number of indicators for each type of farming, $n$ is the number of compared alternatives (countries from the EU-21 which is defined as the EU-28 excluding Belgium, the Netherlands, Greece, Malta, Cyprus, Luxembourg, and Ireland).

The entropy level for the $i$-th indicators within a certain type of farming is denoted as $E_{i}$ and calculated following [75]:

$$
E_{i}=(-1 / \ln n) \sum_{j=1}^{n} \hat{r}_{i, j} \ln \hat{r}_{i, j} ; i=1,2, \ldots, m .
$$

After calculating the degrees of variation for each indicator $\left(d_{i}\right)$ and normalizing them, a vector of weights, $w$, is obtained [75]:

$$
d_{i}=1-E_{i}, w_{i}=\frac{d_{i}}{\sum_{i=1}^{m} d_{i}} .
$$

VIKOR (Vlse Kriterijumska Optimizacija Kompromisno Resenje) method was chosen for aggregating the four performance indicators into the composite indicator. The VIKOR method focuses on ranking alternatives from a finite set of feasible alternatives. The VIKOR method was proposed by Opricovic and Tzeng [76]. The method belongs to a class of multi-criteria methods relying on the reference point approach. As it relies on the two types of distances to the best ("ideal") solutions, it is less sensitive to variations in the initial data.

The VIKOR method uses the linear normalization. In the case of benefit criteria, normalization is carried out as:

$$
\tilde{r}_{i j}=\left(\max _{j} w_{i} r_{i j}-w_{i} r_{i j}\right) /\left(\max _{j} w_{i} r_{i j}-\min _{j} w_{i} r_{i j}\right) .
$$

Normalization of cost criteria is carried out as:

$$
\widetilde{r}_{i j}=1-\frac{\max _{j} w_{i} r_{i j}-w_{i} r_{i j}}{\max _{j} w_{i} r_{i j}-\min _{j} w_{i} r_{i j}}=\frac{\min _{j} w_{i} r_{i j}-w_{i} r_{i j}}{\min _{j} w_{i} r_{i j}-\max _{j} w_{i} r_{i j}},
$$


The VIKOR method uses three measures for the evaluation: $S_{j}, R_{j}, Q_{j}(j=1, \ldots, n)$. Scores, $S_{j}$ and $R_{j}$, are calculated as the $L_{p}$-norms: $S_{j}=\sum_{i=1}^{m} \omega_{i} \widetilde{r}_{i j}$ and $R_{j}=\max _{i}\left(\omega_{i} \widetilde{r}_{i j}\right)$. The aggregate score $Q_{j}$ is calculated as

$$
Q_{j}=\frac{v\left(S_{j}-S^{*}\right)}{S^{-}-S^{*}}+\frac{(1-v)\left(R_{j}-R^{*}\right)}{R^{-}-R^{*}},
$$

where $S^{*}=\min _{j} S_{j}, S^{-}=\max _{j} S_{j}, R^{*}=\min _{j} R_{j}, R^{-}=\max _{j} R_{j}, v=0.5$.

The best performance is related to the smallest distance to the ideal solutions, i.e., the lowest values of $S_{j}, R_{j}$, and $Q_{j}$. The alternatives compared should be arranged in an ascending order of $Q_{j}$. The values of $Q_{j}$ range from 0 to 1 , where the lowest value represents the best result.

\section{Results}

The four criteria used in the construction of the composite indicator are the cost ones (i.e., lower values of the criteria are desirable). The data are pooled across years 2007-2017. First, the entropy method is applied to calculate the weights of the criteria. The resulting weights are presented in Table 1.

Table 1. The weights of criteria based on the entropy method for each farming type.

\begin{tabular}{ccccc}
\hline Criterion & Share of LPCQ in GFI & Share of B in GFI & Share of M in GFI & Share of BL in GFI \\
\hline Type & Cost $(-)$ & Cost $(-)$ & Cost $(-)$ & Cost (-) \\
\hline$E_{i}$ & \multicolumn{2}{c}{ Specialist cereals, oilseeds, and protein crops } & 0.91008 \\
\hline$d_{i}$ & 0.91025 & 0.95134 & 0.98210 & 0.08992 \\
\hline$w_{i}$ & 0.08975 & 0.04866 & 0.01790 & 0.365 \\
\hline$E_{i}$ & 0.364 & 0.198 & 0.073 & 0.98603 \\
\hline$d_{i}$ & 0.92367 & Specialist milk & 0.01397 \\
\hline$w_{i}$ & 0.07633 & 0.96930 & 0.98087 & 0.100 \\
\hline$E_{i}$ & 0.545 & 0.03070 & 0.01913 & 0.136 \\
\hline$d_{i}$ & 0.89544 & 0.219 & & 0.97112 \\
\hline$w_{i}$ & 0.10456 & 0.95162 & 0.97204 & 0.02888 \\
\hline
\end{tabular}

According to the entropy method, the criteria are ordered differently for each farming type. For the specialist cereal, oilseed and protein crop farming, the most important indicators are the shares of BL and LPCQ in the GFI (weights of 0.364 and 0.365), whereas the least important is the share of M in the GFI (0.073). For the specialist milk farming, the most important indicator is the share of LPCQ in the GFI (0.545) and the least important one is the share of BL in the GFI (0.100). For the specialist cattle farming, the most significant indicator is the share of LPCQ in the GFI (0.498), whereas the share of M in the GFI (0.138) is the least important criterion. In order to calculate the VIKOR-based aggregate indicators of the farming performance, the weighted normalized values $w_{i} \widetilde{r}_{i j}$ are used (Table 2). 
Table 2. The weighted normalized decision matrices for the three types of farming in EU-21, 2017.

\begin{tabular}{|c|c|c|c|c|c|c|c|c|c|c|c|c|}
\hline \multirow{2}{*}{$\begin{array}{c}\begin{array}{c}\text { Farming } \\
\text { Types }\end{array} \\
\text { Countries }\end{array}$} & \multicolumn{4}{|c|}{ Specialist Cereals, Oilseeds and Protein Crops } & \multicolumn{4}{|c|}{ Specialist Milk } & \multicolumn{4}{|c|}{ Specialist Cattle } \\
\hline & $\begin{array}{l}\text { Share of } \\
\text { LPCQ in } \\
\text { the GFI }\end{array}$ & $\begin{array}{l}\text { Share of B } \\
\text { in the GFI }\end{array}$ & $\begin{array}{c}\text { Share of } \\
\mathrm{M} \text { in the } \\
\text { GFI }\end{array}$ & $\begin{array}{c}\text { Share of } \\
\text { BL in the } \\
\text { GFI }\end{array}$ & $\begin{array}{l}\text { Share of } \\
\text { LPCQ in } \\
\text { the GFI }\end{array}$ & $\begin{array}{l}\text { Share of B } \\
\text { in the GFI }\end{array}$ & $\begin{array}{c}\text { Share of } \\
\mathrm{M} \text { in the } \\
\text { GFI }\end{array}$ & $\begin{array}{c}\text { Share of } \\
\text { BL in the } \\
\text { GFI }\end{array}$ & $\begin{array}{l}\text { Share of } \\
\text { LPCQ in } \\
\text { the GFI }\end{array}$ & $\begin{array}{l}\text { Share of B } \\
\text { in the GFI }\end{array}$ & $\begin{array}{c}\text { Share of } \\
\mathrm{M} \text { in the } \\
\text { GFI }\end{array}$ & $\begin{array}{c}\text { Share of } \\
\text { BL in the } \\
\text { GFI }\end{array}$ \\
\hline Bulgaria & 0.0100 & 0.0032 & 0.0054 & 0.0204 & 0.0084 & 0.0032 & 0.0052 & 0.0417 & 0.0015 & 0.0000 & 0.0501 & 0.0366 \\
\hline Czechia & 0.0211 & 0.0272 & 0.0146 & 0.0582 & 0.0167 & 0.0405 & 0.0209 & 0.0096 & 0.0154 & 0.0300 & 0.0319 & 0.0156 \\
\hline Denmark & 0.2120 & 0.0839 & 0.0254 & 0.0324 & 0.1935 & 0.0546 & 0.0294 & 0.0173 & 0.1980 & 0.0718 & 0.0335 & 0.0103 \\
\hline Germany & 0.0990 & 0.0168 & 0.0165 & 0.0594 & 0.1157 & 0.0276 & 0.0400 & 0.0226 & 0.0688 & 0.0281 & 0.0362 & 0.0057 \\
\hline Spain & 0.1080 & 0.0134 & 0.0051 & 0.0162 & 0.0705 & 0.0154 & 0.0003 & 0.0727 & 0.0432 & 0.0156 & 0.0078 & 0.0638 \\
\hline Estonia & 0.0203 & 0.0225 & 0.0350 & 0.0105 & 0.0207 & 0.0561 & 0.0329 & 0.0172 & 0.0148 & 0.0217 & 0.0544 & 0.0308 \\
\hline France & 0.0156 & 0.0073 & 0.0153 & 0.2455 & 0.0108 & 0.0344 & 0.0381 & 0.0495 & 0.0072 & 0.0213 & 0.0349 & 0.0744 \\
\hline Croatia & 0.0441 & 0.0324 & 0.0308 & 0.0418 & 0.0633 & 0.0704 & 0.0795 & 0.0242 & 0.0270 & 0.0584 & 0.0539 & 0.0186 \\
\hline Hungary & 0.0261 & 0.0168 & 0.0177 & 0.0426 & 0.0167 & 0.0243 & 0.0152 & 0.0252 & 0.0133 & 0.0270 & 0.0269 & 0.0323 \\
\hline Italy & 0.2982 & 0.0278 & 0.0049 & 0.0034 & 0.0999 & 0.0113 & 0.0035 & 0.0290 & 0.0513 & 0.0198 & 0.0121 & 0.0178 \\
\hline Lithuania & 0.0209 & 0.0104 & 0.0226 & 0.0378 & 0.0367 & 0.0055 & 0.0861 & 0.0169 & 0.0153 & 0.0029 & 0.0615 & 0.0196 \\
\hline Latvia & 0.0247 & 0.0192 & 0.0239 & 0.0399 & 0.0335 & 0.0173 & 0.0266 & 0.0154 & 0.0167 & 0.0131 & 0.0299 & 0.0279 \\
\hline Austria & 0.0224 & 0.0852 & 0.0330 & 0.0043 & 0.0595 & 0.1807 & 0.0963 & 0.0069 & 0.0528 & 0.1293 & 0.0705 & 0.0024 \\
\hline Poland & 0.1265 & 0.0789 & 0.0354 & 0.0341 & 0.1327 & 0.0709 & 0.0822 & 0.0326 & 0.0900 & 0.0872 & 0.0765 & 0.0192 \\
\hline Portugal & 0.0457 & 0.0107 & 0.0085 & 0.1811 & 0.0458 & 0.0063 & 0.0390 & 0.0510 & 0.0224 & 0.0067 & 0.0180 & 0.0306 \\
\hline Romania & 0.0153 & 0.0250 & 0.0142 & 0.0110 & 0.0263 & 0.0680 & 0.0101 & 0.0074 & 0.0105 & 0.0628 & 0.0136 & 0.0117 \\
\hline Finland & 0.1408 & 0.0475 & 0.0369 & 0.0023 & 0.0811 & 0.0713 & 0.0673 & 0.0086 & 0.0300 & 0.0529 & 0.0394 & 0.0000 \\
\hline Sweden & 0.2264 & 0.0586 & 0.0463 & 0.0137 & 0.0724 & 0.0787 & 0.0690 & 0.0295 & 0.0938 & 0.0642 & 0.1157 & 0.0150 \\
\hline Slovakia & 0.0097 & 0.0353 & 0.0124 & 0.0915 & 0.0082 & 0.0480 & 0.0100 & 0.0022 & 0.0015 & 0.0453 & 0.0168 & 0.0082 \\
\hline Slovenia & 0.1214 & 0.1112 & 0.0403 & 0.0366 & 0.1907 & 0.1522 & 0.1077 & 0.0317 & 0.1240 & 0.1486 & 0.1042 & 0.0122 \\
\hline $\begin{array}{l}\text { United } \\
\text { Kingdom }\end{array}$ & 0.3052 & 0.0170 & 0.0241 & 0.1620 & 0.2478 & 0.0088 & 0.0336 & 0.0690 & 0.2211 & 0.0164 & 0.0469 & 0.0502 \\
\hline
\end{tabular}


Decision matrix comprises data for the period of 2007-2017. By considering the normalized values, the two distances from the ideal solution $\left(S_{j}\right.$ and $\left.R_{j}\right)$ are calculated. The resulting distances are further normalized.

The composite VIKOR-based performance indicator shows that, in 2007-2017, Bulgaria, Romania, Hungary, Estonia, and Lithuania were the best performing countries in specialist cereals, oilseeds, and protein crops on average (the values of the composite indicator for these countries ranged from 0.039 to 0.112 ). At the other end of spectrum, Slovenia, France, Denmark, Italy, and the United Kingdom were the worst performing countries (the mean values of the composite indicator ranged from 0.392 to 0.641). Figure 1 presents the results.

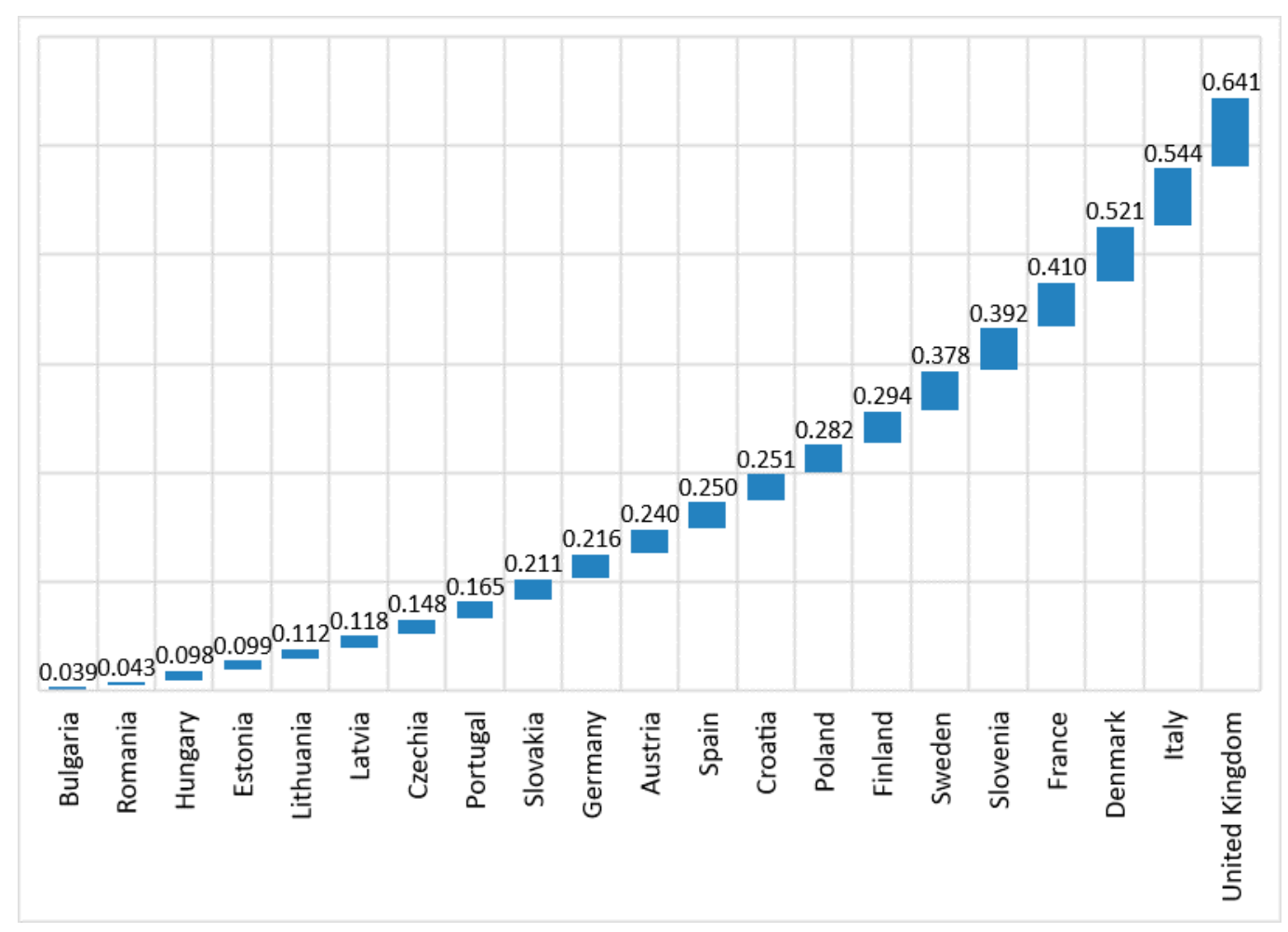

Figure 1. The VIKOR-based composite indicator for specialist cereal, oilseed, and protein crop farms in the EU-21 (averages for 2007-2017).

Analysis of the specialist milk farms revealed that, in 2007-2017, Hungary, Latvia, Bulgaria, Portugal, and Slovakia were the best performing countries (the average values of the composite indicator ranged from 0.038 to 0.073 ). On the contrary, Poland, Austria, the United Kingdom, Slovenia, and Denmark were the worst performing countries (the average values of the composite indicator ranged from 0.303 to 0.504 for 2007-2017). Figure 2 summarizes results for the dairy farms.

As regards specialist cattle farms, the best performing countries were Latvia, Slovakia, Portugal, Bulgaria, and the Czech Republic (the average composite scores for these countries ranged from 0.033 to 0.061 during 2007-2017). The worst performing countries coincided with those mentioned for the milk farms-Poland, Austria, United Kingdom, Slovenia, and Denmark (the mean values of the composite indicator range from 0.212 to 0.461 ). Figure 3 presents the details for the cattle farms. 


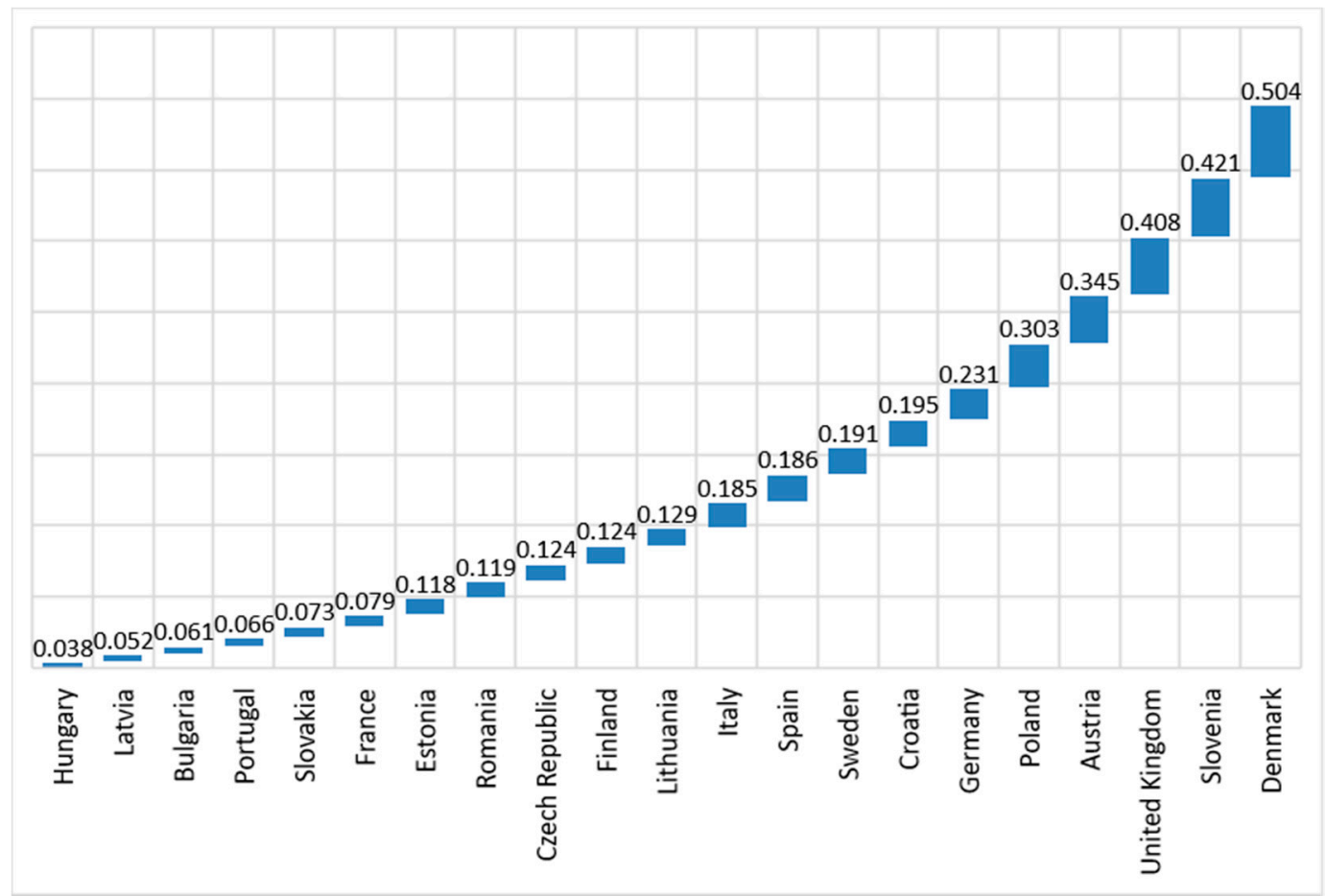

Figure 2. The VIKOR-based composite indicator for specialist milk farms in the EU-21 (averages for 2007-2017).

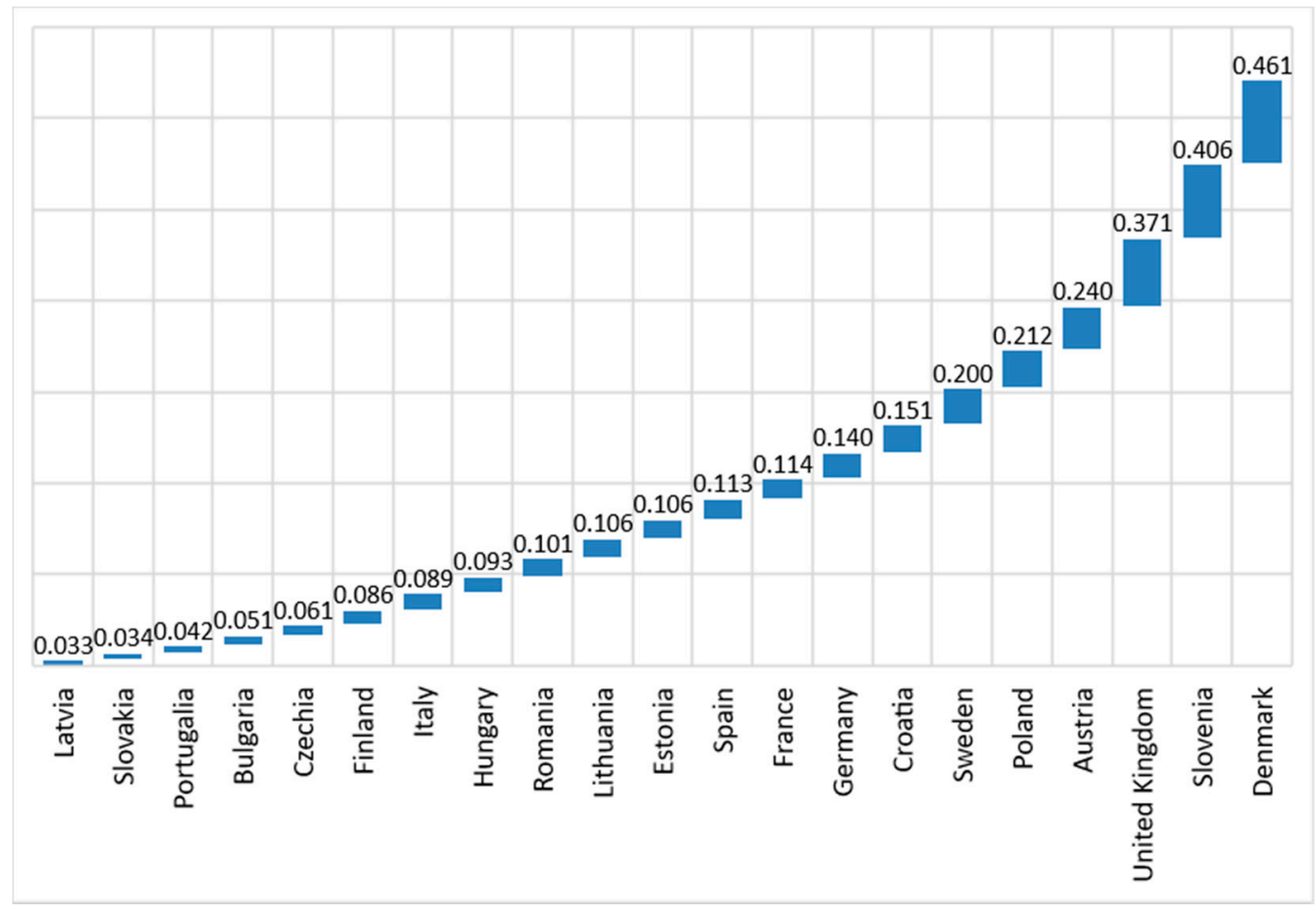

Figure 3. The VIKOR-based composite indicator for specialist cattle farms in the EU-21 (averages for 2007-2017).

The resulting rankings of the countries may appear to be contradictory. Indeed, these results are based on the profitability approach, i.e., the prices of land, machinery, biological assets prevailing across individual EU countries are taken into account. Thus, the new Member States face lower input prices and appear to be better performing. The opposite pattern is observed in the old Member States, 
thus, the differences in the output levels and profits do not compensate the differences in production costs. In the case of the Baltic States, input prices have been increasing since accession to the EU and approaching the EU average levels.

We further examine the relationship between performance of the agricultural sector in selected EU-21 countries and air pollution related to agriculture in these countries. We also consider the high intensity of fertilizer application as a proxy for environmental pressures. The aggregation of the performance indicators rendered by the VIKOR for the three different farming types was carried out by calculating the average score. Table 3 presents the results. Indeed, the correlation among the average industrial performance indicator and the environmental indicators (air pollution in agriculture and share of the land area under high-input farms) for selected countries is strong, i.e., greater than 0.65 (Table 4).

Table 3. Farm industrial performance and environmental indicators in the EU countries (EU-21), average values for 2007-2017.

\begin{tabular}{|c|c|c|c|}
\hline Member State & $\begin{array}{c}\text { Average } \\
\text { Performance }\end{array}$ & High-Input Farms (\% of Area) & Air Pollution, kg/ha \\
\hline Austria & 0.275 & 25.823 & 43.92 \\
\hline Bulgaria & 0.050 & 5.400 & 16.64 \\
\hline Croatia & 0.199 & 30.225 & 33.31 \\
\hline Czech Republic & 0.111 & 21.431 & 19.36 \\
\hline Denmark & 0.495 & 57.992 & 53.26 \\
\hline Estonia & 0.108 & 4.108 & 17.76 \\
\hline Finland & 0.168 & 31.954 & 25.86 \\
\hline France & 0.201 & 44.031 & 22.85 \\
\hline Germany & 0.195 & 62.092 & 60.03 \\
\hline Hungary & 0.076 & 13.200 & 29.37 \\
\hline Italy & 0.273 & 26.569 & 45.92 \\
\hline Latvia & 0.068 & 5.646 & 14.41 \\
\hline Lithuania & 0.116 & 4.600 & 19.67 \\
\hline Poland & 0.265 & 23.723 & 33.71 \\
\hline Portugal & 0.091 & 12.177 & 19.87 \\
\hline Romania & 0.088 & 7.170 & 17.70 \\
\hline Slovakia & 0.106 & 4.685 & 20.68 \\
\hline Slovenia & 0.406 & 31.808 & 52.62 \\
\hline Spain & 0.183 & 14.600 & 31.59 \\
\hline Sweden & 0.256 & 35.031 & 32.15 \\
\hline United Kingdom & 0.473 & 33.238 & 24.05 \\
\hline
\end{tabular}

Source: Average score is calculated as the average of the VIKOR-based performance scores for each observation; Eurostat, 2019 [77]. 
Table 4. Correlation among the average values of the industrial performance and environmental indicators.

\begin{tabular}{cccc}
\hline & Average Performance & High-Input Farms & Air Pollution \\
\hline Average performance & 1 & & \\
\hline High-input farms & 0.679 & 1 & 1 \\
\hline Air pollution & 0.651 & 0.75 & \\
\hline
\end{tabular}

Source: Average score is calculated as the average of the VIKOR-based performance scores for each observation; [77].

This shows that countries with lower performance levels (i.e., a higher value of the aggregate indicator) are also more polluting ones. Meanwhile, most of the EU countries that joined the EU in 2004 show moderate performance and environment-friendly mode of production which follows the concept of sustainable agricultural development (Figures 4 and 5).

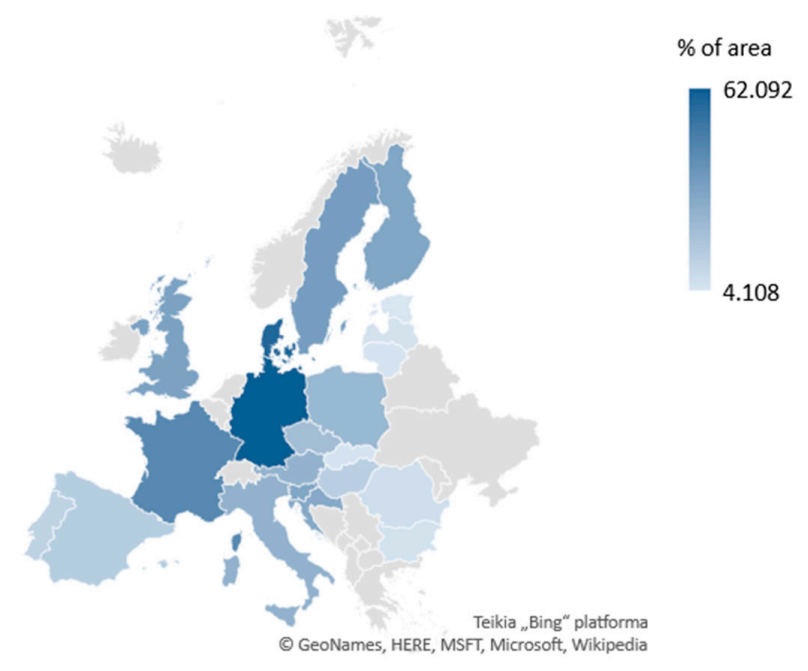

Figure 4. Distribution of the share of high-input farms.

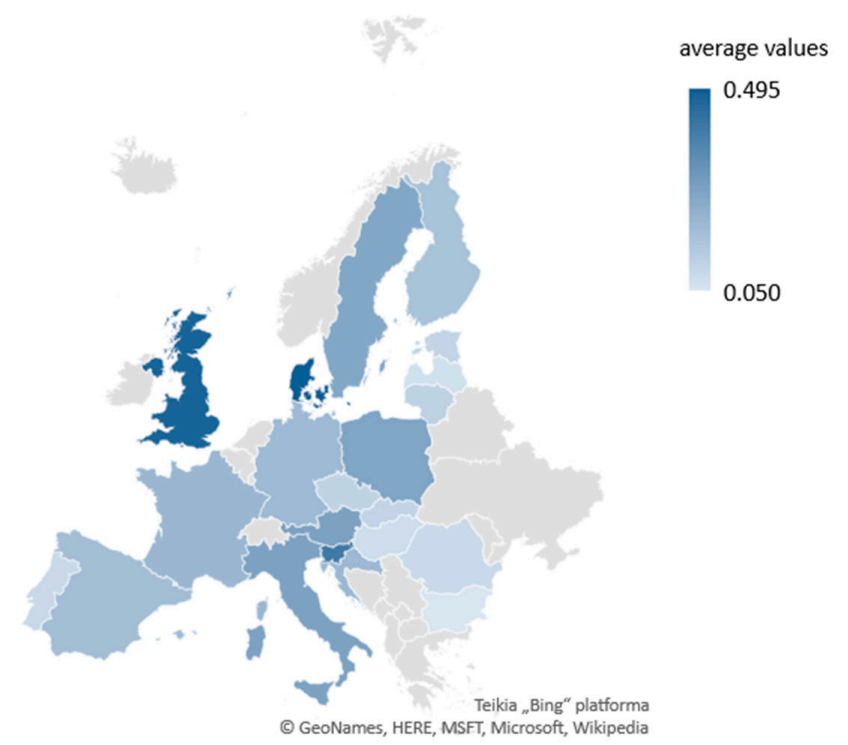

Figure 5. Distribution of the average industrial performance scores. 
The VIKOR-based performance scores are regressed on the covariates describing the structure of the farms across different EU countries and farming types. Note that increasing values of the aggregate performance score imply lower performance as discussed in Section 3. The regressors are chosen to describe the technical and economic aspects of the farm management and operation. The lagged performance scores based on the VIKOR method are included in order to account for the autocorrelation among the scores. The share of the crop output in the total output is included in order to check the effects of specialization. The labor-land ratio is included to account for technological differences. Similar, livestock intensity variable (livestock units to land area) describe the development of livestock farming. Liability-to-asset ratio identifies the integration into capital markets. Logged direct payments per ha or per LU identify the degree of subsidization. The logged economic size of an average farm is included to account for differences in the farm structure. The heating degree days is used as a measure of climatic conditions (the squared logged form is applied). The prices of the capital, land, and labor are accounted for by considering the ratios of costs and input quantities provided in the FADN. Finally, the price recovery ratio (output price index divided by the input price index) is used to account for the market conditions. Table 5 describes the variables used for the regression.

Table 5. Definition of the explanatory variables.

\begin{tabular}{|c|c|c|}
\hline Variable & Description & Source \\
\hline $\begin{array}{l}\text { lag_crop } \\
\text { lag_milk } \\
\text { lag_cattle }\end{array}$ & $\begin{array}{l}\text { The lagged score rendered by the } \\
\text { VIKOR method (specific to each } \\
\text { farming type) }\end{array}$ & Own calculation \\
\hline cropShare & $\begin{array}{l}\text { The ratio of the crop output to the } \\
\text { total output (specific to each } \\
\text { farming type) }\end{array}$ & FADN \\
\hline AWUha & $\begin{array}{l}\text { The ratio of labor input to land } \\
\text { area (specific to each farming type) }\end{array}$ & FADN \\
\hline LUha & $\begin{array}{l}\text { The ratio of LU to land area } \\
\text { (specific to each farming type) }\end{array}$ & FADN \\
\hline lAsset & $\begin{array}{l}\text { The ratio of liabilities top assets } \\
\text { (specific to each farming type) }\end{array}$ & FADN \\
\hline pay & $\begin{array}{l}\text { Direct payments per land area unit } \\
\text { (for crop farms) or per LU (for } \\
\text { milk and cattle farms) }\end{array}$ & FADN \\
\hline ESU & $\begin{array}{l}\text { Economic farm size in Euro } \\
\text { (specific to each farming type) }\end{array}$ & FADN \\
\hline$H D D$ & Heating degree days & Eurostat \\
\hline interest & $\begin{array}{c}\text { The ratio of interest paid to } \\
\text { liabilities (specific to each farming } \\
\text { type) }\end{array}$ & FADN \\
\hline landP & $\begin{array}{l}\text { Land price derived as the ratio of } \\
\text { the rent paid to the rented land } \\
\text { area (specific to each farming type) }\end{array}$ & FADN \\
\hline laborP & $\begin{array}{l}\text { Labor price derived as the ratio of } \\
\text { the wages paid to the paid labor } \\
\text { input (specific to each farming } \\
\text { type) }\end{array}$ & FADN \\
\hline$P R$ & $\begin{array}{l}\text { Price recovery ratio derived by } \\
\text { dividing output price indices (crop } \\
\text { or livestock) by input price index }\end{array}$ & Eurostat \\
\hline
\end{tabular}


The fixed effects two-way panel models are implemented for each farming type. We do not use the censored regression model, as only several observations actually achieve the extreme values of the aggregate performance score (i.e., the value of unity). Note that some data are unavailable for, e.g., Croatia. The insignificant variables are omitted through the backward procedure. The resulting estimates are presented in Table 6.

Table 6. Effects of the farm performance (the panel model).

\begin{tabular}{|c|c|c|c|c|c|c|}
\hline \multirow{2}{*}{ Variable } & \multicolumn{2}{|c|}{ Crop } & \multicolumn{2}{|c|}{ Milk } & \multicolumn{2}{|c|}{ Cattle } \\
\hline & Coefficient & Sig. & Coefficient & Sig. & Coefficient & Sig. \\
\hline lag_crop & 0.262692 & $* *$ & 0.180956 & $* * *$ & 0.145714 & $* *$ \\
\hline lag_milk & -0.27516 & . & & & -0.36626 & $* * *$ \\
\hline lag_cattle & 0.158771 & & 0.202933 & $* * *$ & 0.603742 & $* * *$ \\
\hline cropShare & 0.405328 & . & & & 0.145009 & . \\
\hline AWUha & 4.140393 & . & & & 0.456514 & \\
\hline LUha & 1.931309 & $* *$ & & & & \\
\hline lAsset & -0.29106 & . & -0.46544 & $* * *$ & -0.44095 & $* * *$ \\
\hline $\log ($ pay $)$ & -0.183352 & $* *$ & -0.05683 & * & & \\
\hline $\log (E S U)$ & & & -0.05349 & & & \\
\hline $\log (H D D)$ & & & 2.094569 & * & & \\
\hline $\log (H D D)^{\wedge} 2$ & & & -0.13444 & * & & \\
\hline interest & & & -0.48056 & * & & \\
\hline $\log (\operatorname{land} P)$ & 0.04877 & & 0.044971 & * & & \\
\hline $\log ($ labor $P)$ & -0.07798 & & & & & \\
\hline \multicolumn{7}{|l|}{$P R$} \\
\hline R-Squared & 0.28706 & & 0.34735 & & 0.39904 & \\
\hline $\begin{array}{c}\text { Adj. } \\
\text { R-Squared }\end{array}$ & 0.10882 & & 0.18925 & & 0.26712 & \\
\hline $\begin{array}{c}\text { F-test } \\
(p \text {-value })\end{array}$ & $2.61 \times 10^{-08}$ & & $1.43 \times 10^{-11}$ & & $4.22 \times 10^{-16}$ & \\
\hline
\end{tabular}

The results show that the autocorrelative terms are significant for crop and cattle farm models. The cattle farms show the highest persistence in their performance. Milk farms show only dependence on the lagged performance of the crop and cattle farms. The negative coefficients for the lagged industrial performance score of the milk farms are observed for the crop and cattle farms. This indirectly suggests the possible movement across farming types from the milk sector. One of the possible channels connecting these three farming types is the dynamics in opportunity costs associated with the input use.

The three variables appeared to be insignificant across all the three models. The labor price remained in the crop farm model after the backward procedure even though its coefficient did not significantly differ from zero. As for the price recovery ratio, it was removed from all the models during the backward procedure. This indicates that price data are not significantly driving the performance of farms in the EU. The extensive support under the CAP may have contributed to such a situation. The economic farm size also appeared as an insignificant determinant of the industrial performance, yet it remained in the milk farm model following the backward procedure.

The share of crop output in the total output significantly affects the performance (as represented by the VIKOR-based scores) of the crop and cattle farms. Specifically, the positive coefficients indicate that increasing specialization in crop farming and decreasing specialization in cattle farming 
renders a decline in the performance. Note that the measures used in this study are mostly those defining cost performance. The ratio of the labor-to-land is significant at $10 \%$ for crop farms and indicates decline in industrial performance as the ratio increases. Livestock intensity appears as a significant determinant of performance for the crop farms only. The increasing livestock intensity decreases cost-based performance, even though the increasing farm specialization is also associated with declining performance. Thus, physical farm size indicators are also important as determinants of farm performance besides the economic ones. The increasing share of borrowed capital (as indicated by the liability-to-assets ratio) positively affects crop, milk, and cattle farm performance. This can be explained by the fact that reasonable investment decisions may increase costs and the gross farm income to different extent. Direct payment rate positively impacts the performance of the crop and milk farms (again, note that the coefficients need to be interpreted in an opposite manner as the lower values of the dependent variable represent better performance). This can be explained by the fact that direct payments substantially contribute to the growth in the gross farm income. The farm structure (as represented by the economic farm size indicator) does not significantly affect farm performance. Interest rate improves the performance of the milk farms (coefficient is significant at 10\%). This finding may be related to the increasing pressure for adoption of the efficient farming practices under the increasing competitive pressure. The increasing land price is associated with decreasing milk farm performance. Indeed, the increasing land price may indicate higher opportunity costs for milk farming and decreasing motivation to embark on this activity.

Note that the coefficients of determination are rather low for the models in Table 4 this may be due to several reasons. At the aggregate level, the regional differences may be masked to a certain extent. What is more, non-linearities may be present in the relationships between farm performance and the explanatory variables. Finally, some of the explanatory variables may have been omitted. Therefore, further analysis is needed to gain more insights into the factors of the farm performance.

\section{Conclusions}

The results based on the composite indicator representing agricultural performance showed that the new EU Member States performed better if compared to the old ones with regards to three farming types (crop farming, specialist milk, and specialist cattle farming). This means that in order to achieve the same farming profitability level, one should invest less in the new Member States, compared to the old ones. These results are determined by relatively low prices of the production factors in the new EU Member States. It shows that investments into agricultural production factors (especially, land) in the new Member States may be a reasonable choice as the long-run convergence processes in the EU [78] should diminish the differences in productivity.

The lower levels of the industrial performance obtained for the old EU Member States can be attributed to the higher production costs. They are reflected not only in higher wages, but also higher subsidies-direct payments-which contribute to increasing costs in two ways: The direct financial aid is included into production costs and capitalized in the land price [79]. The comparably low scores of Poland with respect to other new Member States (Slovakia, Hungary) can be attributed to the fact that the average farm holding in Poland (10.2 ha), is much smaller than in Slovakia (73.7 ha). Countries with lower cost-based industrial performance levels (Denmark, the Netherlands, Austria) are among the ones where the direct payments per ha of UAA are the highest. These results suggest that the current EU direct payments scheme under the CAP redistribution mechanism is aimed at supporting low performing countries and is not encouraging the increase in the agricultural performance of the EU Member States. However, further revisions of the financial data in the FADN are necessary to ensure full comparability. The decreasing industrial performance was related to increasing pollution intensity. In this regard, the CAP also needs further revisions in order to ensure that the direct payments induce environment-friendly farming practices.

Regression analysis was carried out to quantify the determinants of farm performance. In the selected EU Member States, crop and cattle farm performance is strongly influenced by the share of 
crop output in the total output, i.e., that less specialized farming can induce cost savings. Increasing leverage (as evidenced by the ratio of liabilities to assets) has a positive impact on dairy and cattle farming. Direct payments also have a positive impact on the performance of crop and milk farms. However, as revealed by the correlation analysis, this effect is not sufficient to reverse the general direct payment-farm performance pattern (and the resulting externalities).

Author Contributions: Conceptualization, V.Š. and A.V.; methodology, M.M. and T.B.; formal analysis, A.V.; investigation, M.M. and T.B.; writing — original draft preparation, A.V. and T.B.; writing—review and editing, M.M. All authors have read and agreed to the published version of the manuscript.

Funding: This research received no external funding.

Conflicts of Interest: The authors declare no conflict of interest.

\section{References}

1. Swinnen, J. Compensation Payments in EU Agriculture. CEPR-Worldbank Paper Working paper. 2009, pp. 1-31. Available online: https://core.ac.uk/download/pdf/6560232.pdf (accessed on 26 November 2019).

2. Djokoto, J.G. Technical efficiency of organic agriculture: A quantitative review. Stud. Agric. Econ. 2015, 117, 67-71. [CrossRef]

3. Oluwatayo, I.B.; Adedeji, T.A. Comparative analysis of technical efficiency of catfish farms using different technologies in Lagos State, Nigeria: A Data Envelopment Analysis (DEA) approach. Agric. Food Secur. 2019, 8, 8. [CrossRef]

4. Piłatowska, M.; Włodarczyk, A. Decoupling Economic Growth from Carbon Dioxide Emissions in the EU Countries. Montenegrin J. Econ. 2018, 14, 7-26. [CrossRef]

5. Sharma, D.; Shardendu, S. Assessing farm-level agricultural sustainability over a 60-year period in rural eastern India. Environmentalist 2011, 31, 325. [CrossRef]

6. Smith, G.; Nandwani, D.; Kankarla, V. Facilitating resilient rural-to-urban sustainable agriculture and rural communities. Int. J. Sustain. Dev. World Ecol. 2017, 24, 485-501. [CrossRef]

7. Veisi, H.; Liaghati, H.; Alipour, A. Developing an ethics-based approach to indicators of sustainable agriculture using analytic hierarchy process (AHP). Ecol. Indic. 2016, 60, 644-654. [CrossRef]

8. De Olde, E.M.; Moller, H.; Marchand, F.; McDowell, R.W.; MacLeod, C.J.; Sautier, M.; Halloy, S.; Barber, A.; Benge, J.; Bockstaller, C.; et al. When experts disagree: The need to rethink indicator selection for assessing sustainability of agriculture. Environ. Dev. Sustain. 2017, 19, 1327-1342. [CrossRef]

9. Latruffe, L.; Diazabakana, A.; Bockstaller, C.; Desjeux, Y.; Finn, J.; Kelly, E.; Ryan, M.; Uthes, S. Measurement of sustainability in agriculture: A review of indicators. Stud. Agric. Econ. 2016, 118, 123-130. [CrossRef]

10. S tanciu, S.; Virlanuta, F.O.; Dinu, V.; Zungun, D.; Antohi, V.M. The Perception of the Social Economy by Agricultural Producers in the North-East Development Region of Romania. Transform. Bus. Econ. 2019, 18, 879-899.

11. Mariyono, J.; Kuntariningsih, A.; Suswati, E.; Kompas, T. Quantity and monetary value of agrochemical pollution from intensive farming in Indonesia. Manag. Environ. Qual. 2018, 29, 759-779. [CrossRef]

12. Djokoto, J.G.; Srofenyo, F.Y.; Arthur, A.A.A. Technical inefficiency effects in agriculture-A meta-regression. J. Agric. Sci. 2016, 8, 109-121. [CrossRef]

13. Nyemeck Binam, J.; Tonye, J.; Wandji, N. Source of technical efficiency among small holder maize and peanut farmers in the slash and burn agriculture zone of Cameroon. J. Econ. Coop. Islam. Count. 2005, 26, 193-210.

14. Bokusheva, R.; Hockmann, H.; Kumbhakar, S.C. Dynamics of productivity and technical efficiency in Russian agriculture. Eur. Rev. Agric. Econ. 2011, 39, 611-637. [CrossRef]

15. Masterson, T. Productivity, Technical Efficiency, and Farm Size in Paraguayan Agriculture; Levy Economics Institute Working Paper No. 490; The Levy Economics Institute: New York, NY, USA, 2007.

16. de Freitas, C.O.; Teixeira, E.C.; Braga, M.J. Technical efficiency and farm size: An analysis based on the Brazilian agriculture and livestock census. Ital. Rev. Agric. Econ. 2019, 74, 33-48.

17. Haq, U.S.; Ceyhan, V.; Boz, I.; Shahbaz, P. Effect of different crop management system on technical efficiency in sugarcane production in Faisalabad, Punjab Region of Pakistan. J. Biol. Agric. Healthc. 2016, 6, 106-114.

18. Schmitz, H. Collective efficiency: Growth path for small-scale industry. J. Dev. Stud. 1995, 31, 529-566. [CrossRef] 
19. Muhammad-Lawal, A.; Omotesho, O.A.; Falola, A. Technical efficiency of youth participation in agriculture: A case study of the youth-in-agriculture programme in ondo state, south western Nigeria. Niger. J. Agric. Food Environ. 2009, 5, 20-26.

20. GÜL, M.; Yilmaz, H.; Parlakay, O.; Akkoyun, S.; Bilgili, M.E.; Vurarak, Y.; Hizli, H.; Kilicalp, N. Technical efficiency of dairy cattle farms in East Mediterranean region of Turkey. Sci. Pap. Ser. Manag. Econ. Eng. Agric. Rural Dev. 2018, 18, 213-226.

21. Błażejczyk-Majka, L.; Kala, R. On the combined estimation of technical efficiency and its application to agriculture. Agric. Econ. 2015, 61, 441-449. [CrossRef]

22. Hřebíková, B.; Čechura, L. An Analysis of the Impacts of Weather on Technical Efficiency in Czech Agriculture. Acta Univ. Agric. Silvic. Mendel. Brun. 2015, 63, 1645-1652. [CrossRef]

23. Diallo, Y.; Marchand, S.; Espagne, E. Impacts of Extreme Climate Events on Technical Efficiency in Vietnamese Agriculture; Études et Documents, n 12, CERDI. 2019. Available online: https://ideas.repec.org/p/hal/ciredw/ halshs-02080285.html (accessed on 17 November 2019).

24. Latruffe, L.; Bravo-Ureta, B.E.; Carpentier, A.; Desjeux, Y.; Moreira, V.H. Subsidies and technical efficiency in agriculture: Evidence from European dairy farms. Am. J. Agric. Econ. 2017, 99, 783-799. [CrossRef]

25. Minviel, J.J.; Latruffe, L. Effect of public subsidies on farm technical efficiency: A meta-analysis of empirical results. Appl. Econ. 2017, 49, 213-226. [CrossRef]

26. Lachaal, L. Subsidies, endogenous technical efficiency and the measurement of productivity growth. J. Agric. Appl. Econ. 1994, 26, 299-310. [CrossRef]

27. Zhu, X.; Milán Demeter, R.; Lansink, A.O. Technical efficiency and productivity differentials of dairy farms in three EU countries: The role of CAP subsidies. Agric. Econ. Rev. 2012, 13, 66-92.

28. Mehta, N. Technical efficiency and reduction in input costs in agriculture: Case of genetically modified cotton. Agric. Econ. Res. Rev. 2019, 32, 105-116. [CrossRef]

29. Siddique, M.A.B.; Sarkar, M.A.R.; Rahman, M.C.; Chowdhury, A.; Rahaman, M.S.; Deb, L. Rice farmers' technical efficiency under abiotic stresses in Bangladesh. Asian J. Agric. Rural Dev. 2017, 7, 219-232.

30. Hasnain, M.N.; Hossain, M.E.; Islam, M.K. Technical efficiency of Boro rice production in Meherpur district of Bangladesh: A stochastic frontier approach. Am. J. Agric. For. 2015, 3, 31-37. [CrossRef]

31. Nowak, A.; Kijek, T.; Domańska, K. Technical efficiency and its determinants in the European Union. Agric. Econ. 2015, 61, 275-283. [CrossRef]

32. Huy, H.T.; Nguyen, T.T. Cropland rental market and farm technical efficiency in rural Vietnam. Land Use Policy 2019, 81, 408-423. [CrossRef]

33. Hoang Linh, V. Efficiency of rice farming households in Vietnam. Int. J. Dev. Issues 2012, 11, 60-73. [CrossRef]

34. Temoso, O.; Hadley, D.; Villano, R. Sources of efficiency, productivity and output growth in Botswana agriculture. Rev. Dev. Econ. 2018, 22, 1105-1124. [CrossRef]

35. Xu, Y.; Zhang, B.; Zhang, L. A technical efficiency evaluation system for vegetable production in China. Inf. Process. Agric. 2018, 5, 345-353. [CrossRef]

36. Souza, G.D.S.; Gomes, E.G. The effect of marketing imperfection variables on production in the context of brazilian agriculture. In Área de Informação da Sede-Artigo em Anais de Congresso (ALICE). International Conference on Operations Research and Enterprises Systems; ScitePress: Funchal, Portugal, 2018; pp. 15-20.

37. Čechura, L. Technical efficiency and total factor productivity in Czech agriculture. Agric. Econ. 2012, 58, 147-156. [CrossRef]

38. Varasani, J.; Shiyani, R.L.; Ardeshna, N.J.; Swaminathan, B. Technical efficiency analysis of groundnut production in Saurashtra region of Gujarat. Int. J. Agric. Sci. 2016, 8, 852-858.

39. Ahmad, D.; Afzal, M. Comparative Analysis of Bt and Non-Bt Cotton Farmers Technical Efficiency of Core Cotton Zone in Punjab Pakistan. Sarhad J. Agric. 2019, 35, 358-368. [CrossRef]

40. Ho, T.T.; Shimada, K. The Effects of Climate Smart Agriculture and Climate Change Adaptation on the Technical Efficiency of Rice Farming-An Empirical Study in the Mekong Delta of Vietnam. Agriculture 2019, 9, 99. [CrossRef]

41. Khataza, R.R.; Hailu, A.; Kragt, M.E.; Doole, G.J. Estimating shadow price for symbiotic nitrogen and technical efficiency for legume-based conservation agriculture in Malawi. Aust. J. Agric. Resour. Econ. 2017, 61, 462-480. [CrossRef]

42. Moreno-Moreno, J.J.; Morente, F.V.; Díaz, M.T.S. Assessment of the operational and environmental efficiency of agriculture in Latin America and the Caribbean. Agric. Econ. 2018, 64, 74-88. 
43. Buckley, C.; Carney, P. The potential to reduce the risk of diffuse pollution from agriculture while improving economic performance at farm level. Environ. Sci. Policy 2013, 25, 118-126. [CrossRef]

44. You, H.; Zhang, X. Sustainable livelihoods and rural sustainability in China: Ecologically secure, economically efficient or socially equitable? Resour. Conserv. Recycl. 2017, 120,1-13. [CrossRef]

45. Nazzaro, C.; Marotta, G. The Common Agricultural Policy 2014-2020: Scenarios for the European agricultural and rural systems. Agric. Food Econ. 2016, 4, 16. [CrossRef]

46. Zeller, M.; Lapenu, C.; Minten, B.; Ralison, E.; Randrianaivo, D.; Randrianarisoa, C. The Critical Triangle Between Environmental Sustainability, Economic Growth, and Poverty Alleviation. In Beyond Market Liberalization: Welfare, Income Generation and Environmental Sustainability in Rural Madagascar; Minten, B., Zeller, M., Eds.; Routledge: Abingdon, UK, 2000; p. 259.

47. Rockström, J.; Williams, J.; Daily, G.; Noble, A.; Matthews, N.; Gordon, L.; Wetterstrand, H.; DeClerck, F.; Shah, M.; Steduto, P.; et al. Sustainable intensification of agriculture for human prosperity and global sustainability. Ambio 2017, 46, 4-17. [CrossRef] [PubMed]

48. Akroyd, H.D. Agriculture and Rural Development Planning: A Process in Transition; Routledge: Abingdon, UK, 2017.

49. Babych, M. Social-economic and environmental sustainability of short supply chains: Opportunities for development rural territories. Agric. Resour. Econ. Int. Sci. E J. 2018, 4, 42-59.

50. Thurlow, J.; Dorosh, P.; Davis, B. Demographic Change, Agriculture, and Rural Poverty. In Sustainable Food and Agriculture; Academic Press: Cambridge, MA, USA, 2019; pp. 31-53.

51. Imai, K.S.; Gaiha, R.; Garbero, A. Poverty reduction during the rural-urban transformation: Rural development is still more important than urbanisation. J. Policy Model. 2017, 39, 963-982. [CrossRef]

52. Kadir, K.; Amalia, R.R. Economic growth and poverty reduction: The role of the agricultural sector in rural Indonesia. In Proceedings of the ICAS VII Seventh International Conference on Agricultural Statistics, Rome, Italy, 24-26 October 2016.

53. Edwards, R.B. Export Agriculture and Rural Poverty: Evidence from Indonesian Palm Oil; Dartmouth College: Hanover, Germany, 2019; Available online: https://static1.squarespace.com/static/57d5edcf197aea51693538dc/ t/5c6cbb1aa4222f75067de956/1550629671736/eard_v9_1901-merged.pdf (accessed on 17 November 2019).

54. Thuita, G.; Ouma, M. Inequality and rural poverty: Innovative agricultural practices for sustainable and social development in Kenya. In Emerging Economic Models for Global Sustainability and Social Development; IGI Global: Hershey, PA, USA, 2019; pp. 84-97.

55. Evans, N.; Yarwood, R. Farm animals and rural sustainability. In Sustainable Rural Systems; Routledge: Abingdon, UK, 2008; pp. 99-114.

56. Mansfield, L. The Cumbria Hill Sheep initiative: A Solution to the Decline in upland Hill Farming Community in England. In Sustainable Rural Systems: Sustainable Agriculture and Rural Communities; Robinson, G., Ed.; Ashgate: Aldershot, UK, 2008; pp. 161-184.

57. Janker, J.; Mann, S.; Rist, S. Social sustainability in agriculture-A system-based framework. J. Rural Stud. 2019, 65, 32-42. [CrossRef]

58. De los Ríos, I.; Rivera, M.; García, C. Redefining rural prosperity through social learning in the cooperative sector: 25 years of experience from organic agriculture in Spain. Land Use Policy 2016, 54, 85-94. [CrossRef]

59. Gathorne-Hardy, A.; Reddy, D.N.; Venkatanarayana, M.; Harriss-White, B. System of Rice Intensification provides environmental and economic gains but at the expense of social sustainability-A multidisciplinary analysis in India. Agric. Syst. 2016, 143, 159-168. [CrossRef]

60. Carles, L.; Joly, M.; Joly, P. Mesotrione herbicide: Efficiency, effects, and fate in the environment after 15 years of agricultural use. Clean Soil Air Water 2017, 45, 1700011. [CrossRef]

61. Bowers, J.K.; Cheshire, P. Agriculture, the Countryside and Land Use: An Economic Critique; Routledge: Abingdon, UK, 2019; Volume 4.

62. Clark, M.; Tilman, D. Comparative analysis of environmental impacts of agricultural production systems, agricultural input efficiency, and food choice. Environ. Res. Lett. 2017, 12, 064016. [CrossRef]

63. Zhang, X.; Bol, R.; Rahn, C.; Xiao, G.; Meng, F.; Wu, W. Agricultural sustainable intensification improved nitrogen use efficiency and maintained high crop yield during 1980-2014 in Northern China. Sci. Total Environ. 2017, 596, 61-68. [CrossRef] 
64. Devkota, M.; Devkota, K.P.; Gupta, R.K.; Sayre, K.D.; Martius, C.; Lamers, J.P. Conservation agriculture farming practices for optimizing water and fertilizer use efficiency in Central Asia. In Managing Water and Fertilizer for Sustainable Agricultural Intensification; Drechsel, P., Heffer, P., Magen, H., Mikkelsen, R., Wichelns, D., Eds.; International Fertilizer Industry Association (IFA), International Water Management Institute (IWMI), International Plant Nutrition Institute (IPNI), and International Potash Institute (IPI): Paris, France, 2015; pp. 242-257.

65. Etingoff, K. Sustainable agriculture: The basics. In Sustainable Agriculture and Food Supply Scientific, Economic and Policy Enhancements; Apple Academic Press: Oakville, ON, Canada, 2016; p. 386.

66. Czyżewski, B.; Matuszczak, A.; Muntean, A. Influence of agricultural policy on the environmental sustainability of European farming. J. Environ. Prot. Ecol. 2018, 19, 426-434.

67. Czyżewski, B.; Majchrzak, A. Market versus agriculture in Poland-Macroeconomic relations of incomes, prices and productivity in terms of the sustainable development paradigm. Technol. Econ. Dev. Econ. 2018, 24, 318-334. [CrossRef]

68. Renwick, A.; Jansson, T.; Verburg, P.H.; Revoredo-Giha, C.; Britz, W.; Gocht, A.; McCracken, D. Policy reform and agricultural land abandonment in the EU. Land Use Policy 2013, 30, 446-457. [CrossRef]

69. Louhichi, K.; Ciaian, P.; Espinosa, M.; Colen, L.; Perni, A.; y Paloma, S.G. Does the crop diversification measure impact EU farmers' decisions? An assessment using an Individual Farm Model for CAP Analysis (IFM-CAP). Land Use Policy 2017, 66, 250-264. [CrossRef]

70. Brookes, G.; Barfoot, P. Environmental impacts of genetically modified (GM) crop use 1996-2015: Impacts on pesticide use and carbon emissions. GM Crops Food 2017, 8, 117-147. [CrossRef]

71. Kuhn, A.; Leibowitz, S.G.; Johnson, Z.C.; Lin, J.; Massie, J.A.; Hollister, J.W.; Bennett, M.G. Performance of national maps of watershed integrity at watershed scales. Water 2018, 10, 604. [CrossRef]

72. Choi, H.S.; Entenmann, S.K. Land in the EU for perennial biomass crops from freed-up agricultural land: A sensitivity analysis considering yields, diet, market liberalization and world food prices. Land Use Policy 2019, 82, 292-306. [CrossRef]

73. Pimentel, D. Handbook of Energy Utilization in Agriculture; CRC Press: New York, NY, USA, 2019; p. 487.

74. European Commission. FADN Public Database. Available online: https://ec.europa.eu/agriculture/rica/ database/database_en.cfm (accessed on 3 February 2020).

75. Hwang, C.L.; Yoon, K. Multiple Attribute Decision Making-Methods and Applications, A State of the Art Survey; Springer: Berlin/Heidelberg, Germany; New York, NY, USA, 1981.

76. Opricovic, S.; Tzeng, G.H. Compromise solution by MCDM methods: A comparative analysis of VIKOR and TOPSIS. Eur. J. Oper. Res. 2004, 156, 445-455. [CrossRef]

77. Eurostat. Database. Available online: https://ec.europa.eu/eurostat/data/database (accessed on 3 February 2020).

78. Crespo Cuaresma, J.; Ritzberger-Grünwald, D.; Silgoner, M.A. Growth, convergence and EU membership. Appl. Econ. 2008, 40, 643-656. [CrossRef]

79. Patton, M.; Kostov, P.; McErlean, S.; Moss, J. Assessing the influence of direct payments on the rental value of agricultural land. Food Policy 2008, 33, 397-405. [CrossRef]

(C) 2020 by the authors. Licensee MDPI, Basel, Switzerland. This article is an open access article distributed under the terms and conditions of the Creative Commons Attribution (CC BY) license (http://creativecommons.org/licenses/by/4.0/). 